\title{
THE COMPANY AS A RESPONSIBLE CORPORATE CITIZEN: AN ANALYSIS OF THE BOARD'S COMMITMENT TO SUSTAINABILITY
}

\author{
Ben Marx* \\ University of Johannesburg \\ benm@uj.ac.za \\ Vanessa van Dyk \\ University of Johannesburg \\ vanessavd@uj.ac.za
}

April 2010

\section{Abstract}

Organisations are increasingly realising that they are members of a wider community and must therefore behave in a responsible manner. The boards of directors of organisations play a critical role in ensuring that companies conduct their business in a responsible and sustainable manner, and in providing accurate, reliable and credible reporting to their stakeholders.

The objective of the paper is twofold: to provide a brief overview of the development of corporate citizenship, sustainability and sustainability reporting and the board's role in this regard; and, secondly, to provide evidence regarding the board's commitment to sustainability as disclosed in a company's sustainability reporting. This is achieved through a literature review of current corporate governance and sustainability developments and practices. This review is supported by empirical evidence obtained from assessing the sustainability reporting of companies through a content analysis of the annual reports of companies listed on the Johannesburg Stock Exchange Limited's Socially Responsible Index. The study found that sustainability and sustainability reporting are widely researched and advocated in the literature, and that companies report a commitment to sustainability, but that these reports lack specific detail concerning the board's responsibility for and commitment to sustainability.

\section{Keywords}

Corporate Citizenship, Corporate Governance, Stakeholders, Sustainability, Socially Responsible Investment (SRI) Index

\footnotetext{
* Prof Ben Marx is professor in Auditing in the Department of Accountancy at the University of Johannesburg, South Africa.

\# Ms Vanessa van Dyk is senior lecturer in Auditing in the Department of Accountancy at the University of Johannesburg, RSA.
} 


\section{INTRODUCTION}

Shareholders and the business world have been shocked over the years by corporate scandals, fraudulent financial reporting and business failures. Environmentalists, human rights activists and society at large have also become more conscious and increasingly concerned about organisations' abuse of the environment and the society in which they operate. Add to this the environmental disasters of recent years such as the extreme droughts, hurricanes and tsunamis experienced all over the world, diseases like HIV/Aids, and the deplorable phenomenon of child labour, and the reality is obvious that sustainability has become an inescapable truth and a key component of modern business (Ackers, 2009; De Villiers 2004; Ernst \& Young 2008a, 2008b; Institute of Directors (hereafter loD), 2009; KPMG, 2008; Piketh, 2010; Van Hille, 2010). Organisations are increasingly realising that they are members of a wider community and must therefore behave in a responsible manner by respecting the environment and society in which they operate and exist. This has resulted in a shift in emphasis from the predominantly financial focus of the past to a wider and more inclusive approach of doing business in the future, moving away from the single bottom line (that is, profits at any cost) to a triple bottom line that embraces the economic, environmental and social aspects of a company's activities (Anonymous, 2009; Ackers, 2009; Cliffe Dekker, 2002; Da Piedade \& Thomas, 2006; Jhaveri, 1998; King, 2006; Marx, 2008; Mitchell, Curtis \& Davidson, 2008; Naidoo, 2009; 0'Carrol, 2009; Paris, 2006; Pearce \& Doh, 2005). Corporate governance developments over the years have also placed an increased emphasis on sustainability and stakeholder inclusivity and in this regard the third King Report on Corporate Governance for South Africa (hereafter King III), which became effective 1 March 2010, remarks that "Sustainability is the primary moral and economic imperative of the $21^{\text {st }}$ century and one of the most important sources of both opportunities and risks for businesses and state that it is also expected of organisations to be, and be seen to be, responsible corporate citizens: this is described as involving "social, environmental and economic issues - the triple context in which companies in fact operate" (IoD, 2009:11-12, 23, Principle 1.2).

Strategy, risk, performance and sustainability have become inseparable and accordingly effective leadership is critical to sustainability and company success. A board of directors (hereafter referred to as the Board) should not make decisions based only on an organisation's present needs, as this may compromise the ability of future generations to meet their own needs: boards should embrace the notion of integrated sustainability performance and reporting (IoD, 2009, Principle 2.2). Sustainability also makes business sense and is directly related to shareholder and stakeholder value (Engelbrecht, 2009; IoD, 2009; Mammatt, 2008; Naidoo, 2009; Van Altena, 2009). Against this background it is evident that boards have a critical role to play to ensure that organisations conduct their business in a responsible and sustainable manner, and further provide accurate, relevant, reliable and credible reporting to their stakeholders on their economic performance, concerning their social, environmental and governance performances and achievements (Dawkins \& Ngunjiri, 2008; loD, nd; Global Reporting Initiative (herafter GRI), 2006; Mammatt, Marx \& Van Dyk, 2010; Mitchell, et.al, 2008; Naidoo, 2009; Tregidga \& Milne, 2007). King III describes this as follows: "the board's role is to set the tone at the top so that the company can achieve this integrated performance" (IoD, 2009:12).

The remainder of this paper is organised as follows: the next section presents the objectives, scope and limitation underpinning the study. The sections that follow describe the theoretical background of the paper, the methodology applied and the empirical findings and deductions. 
Recommendations drawn from the study and areas identified for future research are then provided, with conclusions presented in the last section.

\section{OBJECTIVES, SCOPE AND LIMITATIONS}

The objective of the paper is twofold: to provide a brief overview of the development of corporate citizenship, stakeholders, sustainability and sustainability reporting and the board's role in this regard; and, secondly, to provide evidence regarding the board's commitment to sustainability as disclosed in a company's sustainability reporting. This is done through a literature review of current corporate governance and sustainability developments and practices. This review is supported by empirical evidence obtained from an assessment of the sustainability reporting of companies listed on the Johannesburg Stock Exchange (hereafter JSE) Limited's Socially Responsible (hereafter SRI) Index.

The study has two specific limitations: firstly, the assessment is limited to those companies listed on the SRI index, and the findings might not necessarily be representative of the sustainability reporting practices of non-SRI-listed companies, unlisted entities or public sector institutions; and, secondly, the content analysis techniques of annual and sustainability reports might have specific limitations. Content analysis has limitations, such as the risk of capturing an incomplete picture of the company's business (as noted by Unerman, 2000:667), but is also a widely recognised and accepted research instrument (Ackers, 2009; April, Bosma \& Deglon, 2003; Barack, 2010; Brennan \& Solomon, 2008; Dawkins \& Ngunjiri, 2008; Mirfazli, 2008). The limiting of the study to the assessment of sustainability reporting in the annual reports, sustainability reports and company websites is justified, as such reports are considered important corporate governance and stakeholder documents produced by companies through which they communicate with their investors, as well as their stakeholders at large (Abeysekera, 2007; Bartlett \& Chandler, 1997; Boesso \& Kumar, 2007; De Villiers, 2004; GRI, 2002; Stainbank \& Peebles, 2006; Wiseman,1982). This is further supported by King III, which emphasises the importance of integrated reporting as a means of increasing the trust and confidence of corporate stakeholders and the legitimacy of a company's operations (IOD, 2009:13-14).

\section{THEORETICAL BACKGROUND}

\subsection{Sustainability, stakeholder concepts and corporate citizenship}

The concepts of sustainability, stakeholders and corporate citizenship have been the subject of discussion, debate and research for many years (cf. Adams \& Larrinaga-Gonzalez, 2007; Dawkins \& Ngunjiri, 2008; Mathews, 1997; Tregidga \& Milne, 2004; Wheeler \& Elkington, 2002 and the NonFinancial Reporting and Corporate Social Responsibility website (available from http://www.nfrcsr.org/about/index.htm)). The various corporate governance codes issued over the years also gave prominence to the need for businesses to behave in a responsible manner and to respect the society and the environment in which they do business (for corporate governance codes issued internationally, see the website of the European Corporate Governance Institute at http://www.ecgi.org/codes_/all_co_des.php). Sustainability issues, in South Africa as well as internationally, have gained in importance since the publication of King II (IOD, 2002), which advocated a shift from the single bottom line of profits only, to that of corporate citizenship, sustainability and triple bottom line reporting. These principles have also gained 
momentum internationally through the publications, recommendations and guidelines issued by various institutes, professional bodies and other interested parties (IoD, 2009:11; Naidoo, 2009:245-247).

Sustainable development is a complex notion that seeks to reconcile the goals of economic development and ecological and social well-being. It is widely accepted that the idea originated and was popularised by the United Nations' World Commission for Environment and Development Report (hereafter WCED), Our Common Future (or commonly referred to as the Brundland Report), which defined sustainable development as "development that meets the needs of the present without compromising the ability of future generations to meet their own needs" (Livesey, 2002:315-317; Naidoo, 2009:246; WCED, 1987:43). Various similar definitions have over the years been offered for "sustainability" and "sustainability reporting", with King II introducing the concept of sustainability into corporate governance (IoD, 2002:91, section 4) and defining it as follows: "This means that each enterprise must balance the need for longterm viability and prosperity - of the enterprise itself and the societies and environment upon which it relies for its ability to generate economic value - with the requirement for short-term competitiveness and financial gain". King III, the most recent of the South African corporate governance reports issued to date, has built upon these concepts and now describes sustainability as follows: "the sustainability of a company means conducting operations in a manner that meets existing needs without compromising the ability of future generations to meet their needs. It means having regard to the impact that the business operations have on the economic life of the community in which it operates. Sustainability includes environmental, social and governance issues" (IoD, 2009:126). Sustainability reporting has evolved from the need to communicate with stakeholders regarding the organisation's sustainability activities and performance, and is best described by the GRI reporting guidelines $(2006: 37,40)$ as "the practice of measuring, disclosing, and being accountable for organisational performance while working towards the goal of sustainable development". The GRI guidelines define a sustainability report as "a single, consolidated disclosure that provides a reasonable and balanced presentation of performance over a fixed period". The GRI guidelines are highly regarded and widely used as guidance for what sustainability information companies should report (IoD, 2009; Hartman \& Painter-Morland, 2007; Jones \& Solomon, 2010; Rea, 2009). King III now requires that sustainability reporting and disclosure be integrated with the company's financial reporting (principle 9.2) and defines integrated reporting as: "the holistic and integrated representation of the company's performance in terms of both its finances and its sustainability" (IOD, 2009:121). Sustainability reporting should be widely and easily accessible to stakeholders and is generally provided through the medium of electronic disks, web-based reporting and paper reports (Cuganesan, Ward \& Guthrie, 2006; Ernst \& Young, 2009:6; GRI, 2006).

The concepts of the stakeholder and of stakeholder engagement have also been widely discussed and researched over the years. One of the first definitions was that of Freeman (as quoted by Breckenridge, 2004:27), who defined stakeholders as "any group or individual who can affect or is affected by the achievement of the organisation's objectives." The GRI (2006:40) defines stakeholders broadly as "those groups or individuals that can reasonably be expected to be significantly affected by the organisation's activities, products, and/or services; or whose actions can reasonably be expected to affect the ability of the organisation to successfully implement its strategies and achieve its objectives". Mervyn King, who chaired the King Committee, has a totally different definition for stakeholders, whom he defines as "the licensors of the business of the company". King goes on to state that "today, the licensor of a business is 
not only the regulator who grants the company the licence to operate its business. There are always other licensors - for example, standard-setting or industry bodies; the media; the individual stakeholders linked to the company through its business such as its customers, employees, suppliers, pressure groups, public opinion makers, politicians etc. Any one of these licensors could impact positively or negatively on a business and will definitely be needed when the inevitable downturn is being corrected" (King, 2006:21). King III advocates that a stakeholder-inclusive corporate governance approach should be followed that "recognises that a company has many stakeholders that can affect the company in the achievement of its strategy and long term sustained growth" (IoD, 2009:100). Stakeholder engagement is widely accepted as the foundation of corporate social responsibility and an important mechanism for assisting the organisation in identifying risks and opportunities in relation to current and emerging issues (Gilman, 2009:9). It will also contribute to addressing stakeholders' perceptions and lead to better stakeholder communication and reporting (IoD, 2009:100).

The concept of corporate citizenship is based on the assumption that an organisation is a person, and, like an individual citizen, should act with integrity and in a socially responsible manner (IoD, 2009:11; Smith, 1996:11). Maighan, Ferrell and Hult (1999:456) understand corporate citizenship to designate the activities and organisational processes adopted by businesses to meet their social responsibilities. These and other meanings and definitions attributed to corporate citizenship have crystallised in the meaning attributed thereto in King III: "responsible corporate citizenship implies an ethical relationship of responsibility between the company and society in which it operates. As responsible corporate citizens of the societies in which they do business, companies have, apart from rights, also legal and moral obligations in respect of their economic, social and natural environments. As a responsible corporate citizen, the company should protect, enhance and invest in the wellbeing of the economy, society and the natural environment" (IoD, 2009:117).

It should also be noted that corporate citizenship, stakeholder engagement and sustainability reporting are imperative to ensure the long-term success and continuing existence of an organisation, but they also bring immediate benefits such as increased investor interest, a better corporate reputation and, possibly, an increased customer base (Ernst \& Young, 2008c:2). They also ensure financial gains resulting from cost savings through operational and energy efficiency, revenue opportunities through energy and carbon trading and new product development and green marketing (Ernst \& Young, 2008a:5-6).

\subsection{The board's responsibility for sustainability}

Sustainability and sustainable development are changing business culture and society, with the global challenge of ensuring that organisations' sustainable development practices reverse the previous erosion of natural resources and improve their environmental, social and economic performance (International Federation of Accountants (IFAC), 2010). The key challenge for organisations' leadership is to make sustainability mainstream (IoD, 2009:13), and in the words of Mervyn King for "directors to realise that in carrying out their duties they have to make sure that the sustainability of the business is considered in terms of the assets of planet earth - air, land and water" (Roberts, 2010:14-15). Accordingly, the board needs to provide effective leadership, and, as part of setting the strategic direction of the organisation, needs to take into account all aspects that may affect its ability to achieve its strategic objectives and organisational success, including that of sustainable development (IoD, n.d.:3). Lindie Engelbrecht (Chief Executive of the loD in South Africa) describes this as follows: "leaders need 
to define strategy, provide direction and establish the ethics and values that will influence and guide practices and behaviour with regards to sustainable performance" (Engelbrecht, 2009:4$5)$. King III (IOD, 2009) emphasises the board's responsibility regarding sustainability by including the following principles in the Code: "The board should provide effective leadership based on an ethical foundation" (Principle 1.1); "The board should ensure that the company is and is seen to be a responsible corporate citizen" (Principle, 1.2); and "The board should appreciate that strategy, risk, performance and sustainability are inseparable" (Principle 2.2). The King Report introduced the concept of integrated reporting, meaning a holistic and integrated representation of the company's performance in terms of both its finance and sustainability (IOD, 2009:13-14, 121), and also acknowledged the excellent guidance on sustainability reporting provided in the GRI reporting guidelines (IOD, 2009:109-110). It tasks the audit committee with the responsibility of overseeing the integrity of sustainability issues reported in the integrated report (IOD, 2009:60, 108-110). Directors also need to realise that sustainability aspects are more than just an ethical and moral responsibility for them, but a legal duty which, if neglected, can have serious consequences in the form of fines, penalties and even jail time (Jackson, 2008:13-14). King III also states that the Board should be "the ultimate custodian of the corporate reputation and stakeholder relationships" (IoD, 2009:100).

Directors should ensure that their sustainability reporting is accurate, relevant, transparent and reliable, and that it reflects the board's commitment to sustainability and sustainable performance (GRI, 2006; KPMG, 2010; Martinez \& Crowther, 2008). Thus the reporting should include aspects such as a discussion of the organisation's profile, strategy, key impacts, risks, opportunities, and its commitment to sustainability and information on governance structures regarding sustainability. As stated above, this sustainability reporting should be available and easily accessible for use by the organisation's stakeholders, and accordingly boards should strive to ensure that sustainability reporting is provided through the medium of electronic disks, web-based reporting and paper reports.

\section{METHODOLOGY}

The board's commitment to sustainability as disclosed in its company's sustainability reporting was empirically tested through a content analysis of the sustainability reports of the companies selected for review.

\subsection{Population}

The population for the empirical study was selected as the companies listed on the JSE's SRI Index. The Index was launched in May 2004 in response to the growing awareness of sustainability globally and particularly in South Africa, and has since been a driver for increased attention to responsible investment in emerging markets (JSE, 2009a). The eligible universe for the SRI Index is the FTSE/JSE All Share Index. All companies in the FTSE/JSE Top 40 Index or the FTSE/JSE Mid Cap Index will automatically be assessed, while other companies can elect to be voluntarily assessed for possible inclusion in the Index. Companies are assessed against criteria across the triple bottom line (environment, society and economy) as well as governance criteria. Assessments take place annually during the second half of the year, with the results announced at the end of November each year (JSE, 2009b). While the Index constituency is still dominated by the Top 40 companies ( $55.7 \%$ for 2008), there has been increasing success by medium-sized and smaller companies (JSE, 2009c). 


\subsection{Content analysis of sustainability reports}

The most recently available sustainability reporting of the companies in the population, as contained in the annual reports, sustainability reports and company websites, was inspected between 14 and 31 August 2009. The sustainability reports of all the companies in the population were inspected ( $100 \%$ coverage). The names of the companies in the population are listed in Annexure A.

As noted in section 2 of the article, the limiting of the study to the assessment of sustainability reporting in the annual reports, sustainability reports and company websites is justified, as such reports are considered important corporate governance and stakeholder documents. They are the means by which companies communicate with their investors, as well as their stakeholders at large (Abeysekera, 2007; Bartlett \& Chandler, 1997; Boesso \& Kumar, 2007; De Villiers, 2004; GRI, 2002; Stainbank \& Peebles, 2006; Wiseman, 1982). This is further supported by King III, which emphasises the importance of integrated reporting as a means of increasing the trust and confidence of corporate stakeholders and the legitimacy of its operations (IoD, 2009:113-114).

\subsection{Research control}

The research consisted of analysing the annual reports of the companies listed on the SRI. The analysis was performed using a checklist against which the assurance information of sustainability reporting was measured. The results were tabled and confirmed by an independent adjudicator to ensure their quality and accuracy.

\section{RESEARCH FINDINGS AND INTERPRETATION}

\subsection{Incorporation of sustainability in the organisations' strategy, objectives and values}

\subsubsection{Objective of the analysis}

The objective of this aspect of the analysis was to establish how many of the 60 companies listed on the SRI included sustainability in their strategy, objectives or values, or a combination thereof.

\subsubsection{Findings and deductions}

From TABLE 1 it can be observed that $16(26.67 \%)$ of the companies make no reference to sustainability anywhere in the company's strategic goals. This could be interpreted as an indication that these organisations do not view sustainability as a vital component of doing business. It is noted, however, that the remaining 44 (73.33\%) do incorporate sustainability in their strategy, objectives and/or values, with five out of 60 companies incorporating sustainability in all aspects of their organisations' strategic goals.

This shows a firm commitment by these organisations to ensuring that their businesses are not simply focused on short-term financial objectives but also consider the long-term viability of their company. 
TABLE 1: Incorporation of sustainability in organisations' strategy, objectives and values

\begin{tabular}{lcc} 
& Number & $\%$ \\
\hline Sustainability incorporated in strategy & 9 & 15.00 \\
Sustainability incorporated in objectives & 7 & 11.67 \\
Sustainability incorporated in values & 9 & 15.00 \\
Sustainability incorporated in a combination of strategy, objectives or & 14 & 23.33 \\
values & 5 & 8.33 \\
Sustainability incorporated in strategy, objectives and values & 16 & 26.67 \\
Sustainability not incorporated in strategy, values and/or objectives & 60 & 100.00
\end{tabular}

Source: Sustainability reporting disclosure (own analysis)

This also supports the view of the IoD (n.d.:3) that the board needs to provide effective leadership, and, as part of setting the strategic direction of the organisation, needs to take into account all aspects that may affect the board's ability to achieve their strategic objectives and organisational success, including that of sustainable development.

\subsection{Format and medium of disclosure of sustainability issues and stakeholder communication}

\subsubsection{Objective of the analysis}

The objective of this aspect of the analysis was to establish in what format and through which media sustainability issues are reported and stakeholder communication effected. Options available to companies include the printed annual reports, the printed sustainability reports, the company website and a combination of such options.

\subsubsection{Findings and deductions}

TABLE 2: Format and medium of disclosure of sustainability issues and stakeholder communication

\begin{tabular}{lcc}
\hline & Number & $\%$ \\
\hline No disclosure of sustainability issues and stakeholder communication & 12 & 20.00 \\
Disclosure in printed annual report only & 8 & 13.33 \\
Disclosure in printed sustainability report only & 28 & 46.67 \\
Disclosure on company website only & 1 & 1.67 \\
Disclosure in a combination of printed annual report, printed & 11 & 18.33 \\
sustainability report and/or company website & 60 & 100.00 \\
\hline
\end{tabular}

Source: Sustainability reporting disclosure (own analysis) 
From TABLE 2 it is observed that $12(20 \%)$ companies do not make any disclosure of sustainability issues or stakeholder communication. As is evident from the above findings, the majority of companies $(46.67 \%)$ that made disclosure of sustainability issues and stakeholder communication do so in their printed sustainability reports.

Only $18.33 \%$ of companies use more than one medium to report on such issues to their stakeholders. For such companies, this indicates a maturity in understanding the needs of the users of such information. Many users would like to access company information easily and through an electronic medium. Therefore by using a combination of a printed report and a report accessible on their website, the companies should be meeting their stakeholders' needs.

\subsection{Identification and analysis of board committee responsible for sustainability}

\subsubsection{Objective of the analysis}

The objective of this aspect of the analysis was to establish whether the companies listed on the SRI Index disclose their board committees that take responsibility for sustainability issues, as well as to assess of the composition of such committees, if disclosed. The second aspect of this analysis was to establish whether the company has disclosed the qualifications of such a committee, and, thirdly, identified the chairman and the chairman's designation.

\subsubsection{Findings and deductions}

TABLE 3: Disclosure of board committee and committee composition

\begin{tabular}{|c|c|c|}
\hline & Number & $\%$ \\
\hline No disclosure of board committee or composition of committee & 21 & 35.00 \\
\hline $\begin{array}{l}\text { Disclosure of a board committee, no disclosure of composition of } \\
\text { board committee }\end{array}$ & 1 & 1.67 \\
\hline $\begin{array}{l}\text { Disclosure of board committee indicates committee consists only of } \\
\text { non-executive directors }\end{array}$ & 23 & 38.33 \\
\hline $\begin{array}{l}\text { Disclosure of board committee indicates committee consists only of } \\
\text { executive directors }\end{array}$ & 3 & 5.00 \\
\hline $\begin{array}{l}\text { Disclosure of board committee indicates committee consists only of } \\
\text { other members (such as legal experts etc.) }\end{array}$ & 1 & 1.67 \\
\hline \multirow[t]{2}{*}{$\begin{array}{l}\text { Disclosure of board committee indicates committee consists of a } \\
\text { combination of executive directors, non-executive directors and/or } \\
\text { other members }\end{array}$} & 11 & 18.33 \\
\hline & 60 & 100.00 \\
\hline
\end{tabular}

Source: Sustainability reporting disclosure (own analysis)

From TABLE 3 it is noted that the majority of companies (65\%) disclose a committee for sustainability as well as the composition of such a board, with only 21 companies (35\%) making no such disclosure. Furthermore, the vast majority of companies with such committees have representation of independent non-executive directors or independent external specialists 
serving on such board committees, as only three companies (5\%) have a committee comprising only executive directors. This shows a strong commitment to ensuring that sustainability is dealt with in an objective manner by these organisations.

TABLE 4: Disclosure of qualifications of board committee

\begin{tabular}{lcc}
\hline & Number & $\%$ \\
\hline $\begin{array}{l}\text { No disclosure of qualifications of board committee } \\
\text { Qualifications are disclosed and committee members include }\end{array}$ & 58 & 96.66 \\
$\begin{array}{l}\text { environmental and legal experts } \\
\begin{array}{l}\text { Qualifications are disclosed and committee members include legal } \\
\text { experts }\end{array}\end{array}$ & 1 & 1.67 \\
& 60 & 1.67 \\
\hline
\end{tabular}

Source: Sustainability reporting disclosure (own analysis)

TABLE 4 indicates that the vast majority of companies (96.67\%) make no disclosure of the qualifications of the members of their board committees responsible for sustainability issues. Only two companies disclose the members' qualifications, and in these cases they are environmental and legal experts. As such a committee deals with specialised and sensitive issues, these committees should comprise knowledgeable and skilled persons who can make a valuable contribution to sustainability issues.

TABLE 5: Disclosure of chairman of board committee for sustainability

\begin{tabular}{lcc}
\hline & Number & $\%$ \\
\hline No disclosure of chairman & 50 & 83.33 \\
Chairman is disclosed and is an executive director & 3 & 5.00 \\
Chairman is disclosed and is a non-executive director & 7 & 11.67 \\
\end{tabular}

Source: Sustainability reporting disclosure (own analysis)

Once again, it is noted from TABLE $\mathbf{5}$ that most companies made no disclosure of the chairman of the board committee responsible for sustainability issues. Three companies (5\%) have executive directors as chairmen of the committee, showing a lack of commitment to independence and objectivity on this committee. Only seven companies (11.67\%) have non-executive chairmen of the board committee, indicating that these companies have a commitment to ensuring that sustainability issues are treated objectively and without bias.

\subsection{Identification and analysis of management committee responsible for sustainability}

\subsubsection{Objective of the analysis}

The objective of this aspect of the analysis was to establish, firstly, whether the companies listed on the SRI Index disclose management committees that take responsibility for 
sustainability issues, and, secondly, the occurrence of the disclosure of the composition of this committee. The third aspect of this analysis was to establish whether the company that has identified a management committee responsible for sustainability issues has disclosed the qualifications of such a committee. Lastly, the identification of the chairman of the committee and the chairman's designation will be investigated.

\subsubsection{Findings and deductions}

TABLE 6: Disclosure of management committee and committee composition

\begin{tabular}{|c|c|c|}
\hline & Number & $\%$ \\
\hline $\begin{array}{l}\text { No disclosure of management committee, composition of committee } \\
\text { or board committee }\end{array}$ & 18 & 30.00 \\
\hline $\begin{array}{l}\text { No disclosure of management committee or composition of committee } \\
\text { but disclosure of a board committee }\end{array}$ & 30 & 50.00 \\
\hline $\begin{array}{l}\text { Disclosure of a management committee and a board committee and } \\
\text { their composition }\end{array}$ & 9 & 15.00 \\
\hline $\begin{array}{l}\text { Disclosure of a management committee without disclosure of } \\
\text { composition of committee }\end{array}$ & 1 & 1.67 \\
\hline \multirow[t]{2}{*}{$\begin{array}{l}\text { Disclosure of a management committee and disclosure of composition } \\
\text { of committee }\end{array}$} & 2 & 3.33 \\
\hline & 60 & 100.00 \\
\hline
\end{tabular}

Source: Sustainability reporting disclosure (own analysis)

From TABLE 6 it can be observed that $30 \%$ of companies make no disclosure of a committee, whether a board or management committee, that takes responsibility for sustainability issues. What is further noted is that $50 \%$ of companies have a board committee that is accountable for sustainability issues. Furthermore, nine companies (15\%) show a strong dedication to sustainability issues by having both a board and management committee that can address sustainability for their organisations to ensure that these issues are appropriately dealt with. Thus only 12 (20\%) companies identify a management committee responsible for sustainability issues.

TABLE 7: Disclosure of composition of management committee

\begin{tabular}{lcc}
\hline & Number & $\%$ \\
\hline Members are executive directors only & 2 & 16.67 \\
Members are non-executive directors only & 3 & 25.00 \\
Members are a combination of non-executive and executive directors & 6 & 50.00 \\
and management & 1 & 8.33 \\
No disclosure of management committee composition & 12 & 100.00 \\
\hline
\end{tabular}

Source: Sustainability reporting disclosure (own analysis) 
From TABLE 7 it can be observed that half of the companies (50\%) have management committees tasked with sustainability issues and that these committees consist of a combination of executive and non-executive directors and management. However, such companies should consider including independent external experts in this committee to ensure a full understanding of sustainability issues and to be able to adequately identify and deal with such issues relevant to their organisations.

TABLE 8: Disclosure of qualifications of management committee

\begin{tabular}{lcc}
\hline & Number & $\%$ \\
\hline $\begin{array}{l}\text { No disclosure of qualifications of management committee } \\
\text { Qualifications are disclosed and committee members include }\end{array}$ & 10 & 83.34 \\
environmental and legal experts & 1 & 8.33 \\
Qualifications are disclosed and committee members include legal \\
experts
\end{tabular}

Source: Sustainability reporting disclosure (own analysis)

Once again it can be observed from TABLE 8 that the vast majority of companies (83.34\%) make no disclosure of the qualification of the members of their management committees responsible for sustainability issues. And, again, only two companies disclose the members' qualifications. These qualifications are principally of a legal and environmental nature and are the same qualifications of the board committees set out in TABLE 4. Therefore, companies should strive to ensure that any committee tasked with sustainability issues is composed of suitable skilled and knowledgeable members. This should result in the committee being able to play a valuable role in dealing with sustainability issues.

TABLE 9: Disclosure of the designation of the chairman for management for sustainability

\begin{tabular}{lcc}
\hline & Number & $\%$ \\
\hline No disclosure of chairman & 2 & 16.67 \\
Chairman is disclosed and is an executive director & 3 & 25.00 \\
Chairman is disclosed and is a non-executive director & 7 & 58.33 \\
\hline
\end{tabular}

Source: Sustainability reporting disclosure (own analysis)

The results of this analysis in TABLE 9 echo the results of the analysis of the designation of chairmen of the board committees responsible for sustainability. Three companies (25\%) have executive directors as chairmen of the committee, showing a lack of commitment to independence and objectivity on this committee. Once again, seven companies (58.33\%) have non-executive chairmen of the board committee, indicating that these companies have a commitment to ensuring that sustainability issues are treated objectively and without bias. 


\section{RECOMMENDATIONS AND AREAS FOR FUTURE RESEARCH}

Given the results of this study, it is recommended that boards give careful consideration to their leadership role regarding sustainability and how they exercise their responsibility in this regard. It is also essential that sustainability should be mainstream and incorporated into the organisation's business strategies, objectives and values. It is further recommended that boards form a sustainability committee, properly constituted of members with the required knowledge and experience, to direct and take responsibility for overseeing the organisation's sustainability activities and performance. Boards should also ensure that accurate, reliable and transparent reporting is provided to their stakeholders on their financial and sustainability performance and achievements, as well the board's role and responsibility in this regard. The study focused on companies listed on the JSE's SRI Index and was also performed prior to the implementation of King III. Accordingly it is recommended that an analysis similar to the one undertaken here should be performed on reporting periods after King III became effective in order to assess the impact thereof on sustainability reporting and the role of the board of directors. It is also recommended that this research study be extended to listed companies not on the SRI Index, unlisted and smaller companies and public sector entities.

\section{CONCLUSION}

With the increased focus on sustainability and a society centred on corporate accountability, boards have a critical role to play to ensure that organisations conduct their business in a responsible and sustainable manner, and provide accurate, reliable and credible reporting to their stakeholders.

The study found that sustainability and sustainability reporting are widely researched and advocated in the literature, and that many companies report a commitment to sustainability, but that reports lack specific detail concerning the board's responsibility for and commitment to sustainability.

\section{REFERENCES}

Abeysekera, I. (2007). Intellectual capital reporting between a developing and developed nation. Journal of Intellectual Capital, 8(2), pp. 329-345.

Ackers, B. (2009). Corporate social responsibility assurance: how do South African publicly listed companies compare? Meditari Accountancy Research, 17(2), pp. 1-17.

Adams, C.A. \& Larrinaga-Gonzalez, C. (2007). Engaging with organisations in pursuit of improved sustainability accounting and performance. Accounting, Auditing \& Accountability Journal, 20(3), pp. $333-355$.

April, K.A., Bosma, P. \& Deglon, D.A. (2003). IC Measurement and Reporting: Establishing a Practice in SA Mining. Journal of Intellectual Capital, 4(2), pp. 165-180.

Anonymous. (June/July 2009). Carbon Accounting Too Little Too Late? BusinessBrief, pp. 536-538. 
Barack, K. (2010). Assessment of Corporate Governance Reporting in the Annual Reports of South African Listed Companies. The South African Journal of Accountability and Auditing Research, Unpublished but accepted for publication, 10(1).

Bartlett, S.A. \& Chandler, R.A. (1997). The corporate report and the private shareholder: Lee and Tweedie twenty years on. British Accounting Review, 29(3), pp. 245-264.

Boesso, G. \& Kumar, K. (2007). Drivers of corporate voluntarily disclosure: A framework and empirical evidence from Italy and the United States. Accounting, Auditing and Accountability Journal, 20(2), pp. 269-296.

Breckenridge, R.G. (2004). Modelling ethical corporate governance in terms of the King Report. Unpublished MBA Research Report. Johannesburg: University of the Witwatersrand.

Brennan, N. \& Solomon, J. (2008). Corporate governance, accountability and mechanisms of accountability: an overview. Accounting, Auditing \& Accountability, 21(7), pp. 885-906.

Cliffe Dekker. (2002). King Report on Corporate Governance for South Africa 2002: What it means to you. Available from: http://www.mbendi.co.za/cliffedekker/literature/corpgov/. (Accessed 19 November 2002)

Cuganesan, S., Ward, L. \& Guthrie, J. (2007). Disclosure Media for Social and Environmental Matters within the Australian Food and Beverage industry. Presented to the $30^{\text {th }}$ Annual Congress of the European Accounting Association: 25-27 April. Lisbon, Portugal.

Da Piedade, L. \& Thomas, A. (2006). The case for corporate responsibility: an exploratory study. SA Journal of Human Resource Management, 4(2), pp. 65-74.

Dawkins, C., \& Ngunjiri, F.W. (2008). Corporate Social Responsibility Reporting in South Africa. Journal of Business Communication, 45(3), pp. 286-307.

De Villiers, C.J. (2004). Ethical arguments regarding corporate environmental reporting. Meditari Accountancy Research, 12(1), pp. 21-38.

Engelbrecht, L. (April/May/June 2009). All the King's horses and all the King's men. Directorship, pp. $4-5$.

Ernst \& Young. (2008a). Green for go: Supply chain sustainability. EYGM Limited. AU0116.

Ernst \& Young. (2008b). Ready or not, here comes sustainability. EYGM Limited. DC0038.

Ernst \& Young. (2008c). Business and sustainability. EYGM Limited. SCORE retrieval file 080626.

Ernst \& Young. (2009). What will you leave behind you. Excellence in Sustainability Reporting. South Africa.

Gilman, K. (2009). Stakeholder Engagement: Vital in business strategy and approach. Excellence in Sustainability Reporting, 2009. South Africa.

Global Reporting Initiative (GRI). (2002). Sustainability Reporting Guidelines (Version 2), GRI, Boston. USA.

Global Reporting Initiative (GRI). (2006). Sustainability Reporting Guidelines (Version 3), GRI, Boston. USA.

Hartman, L.P. \& Painter-Morland, M. (2007). Exploring the Global Reporting Initiative (GRI) Guidelines as a model for triple bottom line reporting. African Journal of Business Ethics, 2(1), pp. 20-22. 
Institute of Directors (IoD). (n.d.). Sustainable Development Forum. (Sponsored by Standard Bank). Position Paper l - Implementing Sustainable Development as a Strategic Business Model.

Johannesburg: Institute of Directors.

Institute of Directors (IoD). (2002). King // Report on Corporate Governance. Institute of Directors in Southern Africa. Johannesburg: Institute of Directors.

Institute of Directors (IoD). (2009). King Report on Corporate Governance for South Africa. Institute of Directors in Southern Africa. Johannesburg: Institute of Directors.

International Federation of Accountants (IFAC). (2010). Professional Accountants in Business, At the Heart of Sustainability. Available from: http://web.ifac.org/sustainability-framework/overview.

(Accessed 30 March 2010)

Jackson, M. (2008). Why health and safety at work is your responsibility. Excellence in Sustainability Reporting, 2008. EYGM Limited. Score Retrieval File 080806. South Africa.

Jhaveri, N.J. (1998). Corporate Governance: The Concept and its Implications in the Indian Context. ASCP Journa/ of Management. Available from: http://www.asci.org.in/publications/journal1998.asp. (Accessed 21 November 2002)

Jones, M.J. \& Solomon, J.F. (2010). Social and environmental report assurance: Some interview evidence. Accounting Forum, 34, pp. $20-31$.

JSE Limited (JSE). (2009a). We/come to the JSE SRI Index. Available from: http://www.jse.co.za/sri/. (Accessed 11 April 2009)

JSE Limited (JSE). (2009b). Johannesburg Stock Exchange SRI Index: Background and selection criteria. JSE and EIRIS.

JSE Limited (JSE). (2009c). JSE SRI Index: Development of Index. Available from: http://www.jse.co.za/sri/development_index.jsp. (Accessed 11 April 2009)

King, M.E. (2006). The Corporate Citizen. Johannesburg: Penguin Books.

KPMG. (2008). Climate Changes Your Business. KPMG Global Sustainability Services. Amstelveen, The Netherlands.

KPMG. (2010). Integrated reporting: Closing the loop of strategy. Available from:

http://www.kpmg.com/Global/en/IssuesAndInsights/ArticlesPublications/Documents/IntegratedReporting.pdf. (Accessed 22 November 2010)

Livesey, C. (2002). The Discourse of the Middle Ground: Citizen Shell Commits to Sustainable Development. Management Communication Quarterly, 15, pp. 313-348.

Maighan, I, Ferrell, O.C. \& Hult, G.T.M. (1999). Corporate Citizenship: Cultural Antecedents and Business Benefits. Journal of the Academy of Marketing, 27(4), pp. 455-469.

Mammatt, J. (2008). Business and sustainability. EYGM Limited.

Mammatt, J., Marx, B. \& Van Dyk, V. (January 2010). Sustainability reporting and assurance: the way of the future. Accountancy SA (ASA), pp. 22-24.

Martinez, \&.0. \& Crowther, D. (2008). Is disclosure the right way to comply with stakeholders? The Shell Case. Business Ethics: A European Review, 17(1), pp. 13-22.

Marx, B. (2008). An analysis of the development, status and functioning of audit committees at large listed companies in South Africa. Unpublished D.Com thesis. Johannesburg: University of Johannesburg. 
Mathews, M.R. (1997). Twenty-five years of social and environmental accounting research: Is there a silver jubilee to celebrate? Equality Diversity and Inclusion: An International Journal, 10(4), pp. 481531.

Mitchell, M., Curtis, A. \& Davidson, P. (2008). Evaluating the process of triple bottom line reporting: Increasing the potential for change. Local Environment, 13(2), pp. 67-87.

Mirfazli, $\varepsilon$, (2008). Evaluate corporate social responsibility disclosure at Annual Report Companies in multifarious group of industry members of Jakarta Stock Exchange (JSX), Indonesia. Social Responsibility Journal, 4(3), pp. 388-406.

Naidoo, R. (2009). Corporate Governance - An Essential Guide for South African Companies. Durban: LexisNexis.

0'Carroll, M. (2009). The natural environment as an integral part of the triple bottom line. Available from: http://ujdigispace.uj.ac.za:8080/dspace/handle/10210/2030. (Accessed 21 November 2009)

Paris, T.M. (June 2006). Corporate Sustainability reporting. Environment, p. 3.

Pearce, J.A. \& Doh, J.P. (2005). The Highest Impact of Collaborative Social Initiatives. MIT Sloan Management Review, 46(3), pp. 30-39.

Piketh, S.J. (January 2010). SA's reality in terms of climate change and sustainable development. Accountancy SA (ASA), p. 16.

Rea, H. (2009). King I/I and GRI + 10: A 2009 review of sustainability reporting in South Africa. Johannesburg: Sustainability Services.

Roberts, L. (2010). (January 2010). Mervyn King speaks frankly about Sustainability Reporting. Accountancy SA (ASA), pp. 14-15.

Smith, N.C. (9 August 1996). Corporate Citizens and Their Critics. New York Times, p. 11.

Stainbank, L. \& Peebles, C. (2006). The usefulness of corporate annual reports in South Africa: perceptions of preparers and users. Meditari Accountancy Research, 14(1), pp. 69-80.

Tregidga, H. \& Milne, M.J. (2007). From Sustainable Management to Sustainable Development: A Longitudinal Analysis of External Communication by a Leading Environmental Reporter. Available from:

http://eprints.otago.ac.nz/4/1/FROM_SUSTAINABLE_MANAGEMENT_TO_SUSTAINABLE_DEVELOPMENT.p df. (Accessed 20 November 2009)

Unerman, J. (2000). Methodological issues - Reflections on quantification in corporate social reporting content analysis. Accounting, Auditing \& Accountability Journal, 13(5), pp. 667-681.

Van Altena, R. (July 2009). Sustainability, Corporate Social Responsibility through an Audit Committee Lens. IA Adviser, p. 42.

Van Hille, N. (April 2010). Sustainability: an opportunity for smaller accounting practises. Accountancy SA (ASA), p. 16.

Wheeler, D. \& Elkington, J. (2002). The recent history of environmental and social reporting. SustainAbility. Available from: http://www.sustainability.com/programs/engaging/historyreporting.asp. (Accessed 21 November 2002)

Wiseman, J. (1982). An evaluation of environmental disclosure made in corporate annual reports. Journal of Accounting, Organisation and Society, 7(1), pp. 53-63.

World Commission for Environment and Development. (WCED). (1987). Our Common Future [The 
Brundland Report]. 0xford: Oxford University Press. 


\section{ANNEXURE A:}

\section{NAMES OF COMPANIES IN THE POPULATION WHOSE SUSTAINABILITY REPORTS WERE INSPECTED}

ABSA Group Limited

AdvTech Limited

African Bank Investments Limited

African 0xygen Limited

African Rainbow Minerals

Allied Electronics Corporation Limited

Allied Technologies Limited

Anglo American plc

Anglo Platinum Limited

AngloGold Ashanti Limited

Aveng Limited

Barloworld Limited

BHP Billiton plc

The Bidvest Group Limited

Brait SA

Capitec (deleted from the index on

19/12/2008)

Discovery Holdings Limited

Exxaro Resources Limited

Firstrand Limited

Foschini

Gold Fields Limited

Grindrod Limited

Group Five Limited

Harmony Gold Mining Company Limited

Highveld Steel and Vanadium Corporation Limited

Hulamin

Illovo Sugar Limited

Impala Platinum Holdings Limited

Investec Limited and Investec plc
JSE Limited

Kumba Iron Ore

Liberty Group Limited

Liberty International plc

Lonmin

Massmart Holdings Limited

Medi-Clinic Corporation Limited

Merafe Resources Limited

Metropolitan Holdings Limited

Mondi

MTN Group Limited

Murray \& Roberts Holdings Limited

Nampak

Nedbank Group Limited

Netcare

Northam Platinum Limited

Oceana Group Limited

Old Mutual plc

Pick n Pay Holdings Limited

Pretoria Portland Cement Company Limited

Remgro Limited

SAB Miller plc

Sanlam Limited

Santam Limited

Sappi Limited

Standard Bank Group Limited

Sun International Limited

Telkom SA Limited

Tongaat Hulett

Truworths International

Woolworths Holdings Limited 